\title{
ГРАЖДАНСКО-ПРАВОВАЯ ПРИРОДА ДОГОВОРА ОБ УЧАСТИИ В ДОЛЕВОМ СТРОИТЕЛЬСТВЕ
}

\begin{abstract}
Аннотация: В настоящей статье дается общая характеристика договора об участии в долевом строительстве как инвестиционного договора, имеющего гражданско-правовую природу, рассмотрены права и обязанности сторон договора об участии в долевом строительстве, проведен анализ нормативноправовых актов, регулирующих данную сферу, судебная практика.

В результате проведенного исследования автор приходит к выводу, что ФЗ о долевом строительстве в значительной степени урегулировал вопросы, связанные с правовым регулированием инвестиционной деятельности в жилищном строительстве, и способствует установлению стабильности в отношениях, складывающихся между застройщиками и долевыми участниками. Однако еще остаются вопросы, требующие законодательной регламентации.
\end{abstract}

Ключевые слова: договор об участии в долевом строительстве; инвестиции; инвестиционная деятельность.

Л юбые договорные отношения, урегулированные нормами гражданского права, должны быть обличены в определенную форму. Так, в зависимости от субъектного состава отношений, их предмета и иных особенностей в Гражданском кодексе Российской Федерации (далее - ГК РФ) предусмотрены соответствующие виды договоров ${ }^{1}$. В свою очередь, отсутствие конкретного вида договора в ГК РФ не умаляет его гражданско-правовой природы, если он отвечает требованиям, предъявляемым самим кодексом (главы 27-29 части первой ГК РФ)², т.е. такой договор не будет являться нетипичным для регулируемой нормами гражданского права области общественных отношений. Причем сам ГК РФ вообще говорит о том, что стороны могут заключить договор как предусмотренный, так и не предусмотренный законом или иными правовыми актами.

В свою очередь, М.Н. Илюшина полагает, что нельзя считать нетипичным явлением договор, урегулированный федеральным законом или иным нормативным правовым актом, содержащим нормы гражданского законодательства, так как в данном случае уже имеет место специальное регулирование возник-

\footnotetext{
1 Гражданский кодекс Российской Федерации (часть вторая) от 26.01.1996 № 14-Ф3 (ред. От 01.01.2012)//С3 РФ, 29.01.1996, № 5, ст. 410.

2 Гражданский кодекс Российской Федерации (часть первая) от 30.11.1994 № 51-Ф3 (ред. от 01.07.2012)//С3 РФ, 05.12.1994, № 32, ст. 3301.
}

ших общественных отношений³. Подобное замечание в полной мере касается договора долевого участия в строительстве многоквартирного дома, который позволяет гражданам осуществлять инвестирование через профессиональных посредников. И хотя настоящая договорная форма не поименована в ГК РФ, договор долевого участия в строительстве отвечает признакам гражданско-правового договора.

Надо заметить, что на протяжении всего времени использования подобной договорной конструкции, пока не был принят специальный закон - Федеральный закон «Об участии в долевом строительстве многоквартирных домов и иных объектов недвижимости и о внесении изменений в некоторые законодательные акты РФ» (далее - ФЗ о долевом строительстве) ${ }^{4}$, велись споры о гражданско-правовой природе договора долевого участия в строительстве, а нередко, напротив, этот договор отождествляли с договором простого товарищества. Более того, Президиум ВАС РФ в обзоре практики разрешения арбитражными судами споров, связанных с договорами на участие в строи-

\footnotetext{
${ }^{3}$ См.: Илюшина М.Н. Правовой режим сделок в коммерческих отношениях: вопросы становления в доктрине, законодательстве и правоприменительной практике: монография. М.: РПА Минюста России, 2011. С. 159.

${ }^{4}$ См.: Федеральный закон от 30.12.2004 № 214-Ф3 (в ред. от 10.07.2012) «Об участии в долевом строительстве многоквартирных домов и иных объектов недвижимости и о внесении изменений в некоторые законодательные акты Российской Федерации»//С3 РФ, 03.01.2005, № 1 (часть 1), ст. 40.
} 


\section{Политика и общество 2 (98) • 2013}

тельстве, предложил договор долевого участия в строительстве рассматривать как договор о совместной деятельности (договор простого товарищества) 5 . Настоящую договорную форму относили даже к разряду договоров возмездного оказания услуг, строительного подряда, купли-продажи недвижимости ${ }^{6}$.

С принятием же Ф3 о долевом строительстве этот вопрос был снят, и настоящий договор, который можно справедливо отнести к разряду инвестиционных ${ }^{7}$, является самостоятельной правовой формой договорных отношений. И в этой связи необходимо отметить, что должный уровень правового регулирования договорных отношений участников инвестиционной деятельности представляется одним из важнейших элементов правового регулирования всего инвестиционного процесса ${ }^{8}$.

Итак, в классическом понимании договор участия в долевом строительстве представляет собой договор, по которому одна сторона (заказчик) обязуется осуществить вложение инвестиций другой стороны (инвестора) в строительство объекта недвижимости и по окончании передать результат последнему, а инвестор обязуется передать инвестиции заказчику и оплатить его услуги. Договор является двусторонним, поскольку заключается каждым долевым участником с застройщиком отдельно, и возмездным. Кроме того, указанный договор подлежит обязательной государственной регистрации и считается заключенным только с момента такой регистрации.

Статьей 25.1 Федерального закона «О государственной регистрации прав на недвижимое имущество и сделок с ним» ${ }^{9}$ установлено требование, в соответствии с

${ }^{5}$ См.: Информационное письмо Президиума ВАС РФ от 25.07.2000 № 56 «Обзор практики разрешения арбитражными судами споров, связанных с договорами на участие в строительстве»//Вестник ВАС РФ, № 9, 2000.

${ }^{6}$ См.: Правовое регулирование инвестиций в жилищном строительстве. Долевое участие граждан в инвестировании строительства жилья./http://portal-law.ru/articles/strinv.

7 См.: Сокол П.В. Инвестиции в жилищное строительство: понятие и правовые формы.// Законы России: опыт, анализ, практика. 2011. № 1. С. 23 - 29.

${ }^{8}$ См.: Козлова Е.Б. Инвестиционный договор: понятие и место в системе гражданско-правовых договоров по дихотомическому принципу: монография/Е.Б. Козлова; РПА Минюста России. - М., 2011. С. 69.

${ }^{9}$ Федеральный закон от 21.07.1997 № 122-Ф3 (ред. от 28.07.2012) «О государственной регистрации прав на недвижимое имущество и сделок с ним»//СЗ РФ, 28.07.1997, № 30, ст. 3594. которым государственная регистрация договора участия в долевом строительстве, заключенного застройщиком с первым участником долевого строительства, осуществляется на основании заявления сторон договора (застройщика, участника долевого строительства). На государственную регистрацию договора участия в долевом строительстве, заключенного застройщиком с первым участником долевого строительства, наряду с документами, необходимыми для государственной регистрации договора, представляются: разрешение на строительство; проектная декларация; план создаваемого объекта недвижимого имущества с указанием его местоположения и количества находящихся в составе создаваемого объекта недвижимого имущества жилых и нежилых помещений и планируемой площади каждого из указанных помещений.

При этом в государственной регистрации договора участия в долевом строительстве может быть отказано, если этот же объект долевого строительства ранее подлежал государственной регистрации в рамках другого договора участия в долевом строительстве. В свою очередь, вышеуказанный федеральный закон регламентирует и иные основания отказа в государственной регистрации.

Как справедливо замечено группой авторов монографии «Инвестиционная активность населения на рынке жилищного строительства» ${ }^{10}$, одним из первых документов, определяющим перспективы дальнейшего строительства многоквартирного жилого дома является Постановление главы администрации города о предварительном согласовании места размещения объекта недвижимости. В соответствии с ним за застройщиком резервируется земельный участок и предписывается осуществить кадастровый учет участка, произвести инвентаризацию существующих строений, в установленном законодательством порядке решить вопросы сноса самовольных построек и осуществить перенос действующих сетей (если таковые имеются), и, в итоге, предоставить документы для принятия решения о предоставлении земельного участка. Другими словами, за застройщиком закрепляется обязанность по устранению существующих на участке обременений и подготовке документации.

\footnotetext{
${ }^{10}$ См.: Инвестиционная активность населения на рынке жилищного строительства: Моногр./И.Ф. Кульков А.А., Рожков В.Л., Харисова Р.Р., Казанский гос. арх.-строит. ун-т, Объед. молод. строительства РТ. - Казань, РЦМИПП, 2011. C. 47.
} 
Надо сказать, что типовой договор долевого участия в строительстве многоквартирного дома имеет форму классического договора, отвечающего всем канонам гражданского права. Практика составления подобного договора такова, что последний включает в себя следующие элементы: 1) общие положения; 2) предмет и цена договора; 3 ) содержание правоотношений, возникающих в рамках настоящего договора; 4) ответственность сторон и порядок освобождения от ответственности (форс-мажор); 5) положения о качестве предмета договора (гарантия качества); 6) порядок передачи объекта долевого строительства; 7) положение об одностороннем отказе от исполнения договора; 8) уступка прав требований по договору; 9) порядок обеспечения исполнения обязательств по договору.

В разделе «Общие положения» дается информация о застройщике, в состав которой входит целый перечень документов: учредительные документы; свидетельство о государственной регистрации; аудиторское заключение; утвержденные бухгалтерские документы (баланс, отчет о прибылях и убытках); официально согласованная проектная документация и ряд других документов. Дается описание объекта долевого строительства, соответствующее проектной документации. Кроме того, указывается подробная информация непосредственно о самом проекте строительства.

Естественно, предмет и цена договора, порядок уплаты являются существенными условиями, и они должны быть подробно регламентированы.

Так, в рамках договора о долевом участии в строительстве многоквартирного дома застройщик ${ }^{11}$ обязуется в предусмотренный договором срок своими силами и (или) с привлечением других лиц построить (создать) многоквартирный дом, и после получения разрешения на ввод в эксплуатацию этого объекта передать объект долевого строительства участнику долевого строительства, а участник долевого строительства обязуется уплатить обусловленную цену договора и принять объект долевого строительства при наличии разрешения на ввод

\footnotetext{
11 Федеральный закон к категории «застройщик» относит юридическое лицо или индивидуального предпринимателя, имеющих в собственности или на праве аренды земельный участок и привлекающих денежные средства участников долевого строительства для строительства (создания) на этом земельном участке многоквартирных домов и (или) иных объектов недвижимости на основании полученного в установленном порядке разрешения на строительство.
}

в эксплуатацию многоквартирного дома. В данном случае предметом договора является совместная деятельность по инвестированию и строительству для долевого участника части объекта.

Содержание правоотношений раскрываются через установление взаимно-корреспондирующих прав и обязанностей сторон. Так, например, обязанности участника долевого строительства вносить в счет участия в долевом строительстве денежные средства в соответствии с графиком платежей корреспондирует право застройщика требовать внесение денежных средств в срок, установленный договором. В свою очередь, обязанности застройщика использовать денежные средства, полученные от участника долевого строительства, по целевому назначению - на строительство объекта корреспондирует право участника требовать неукоснительного исполнения этого требования договора.

Кроме того, большое внимание уделяется закреплению оснований привлечения стороны договора к ответственности. Например, участник долевого строительства будет вынужден выплатить неустойку (пени) в случае нарушения установленного срока внесения платежа. В свою очередь, в случае нарушения срока передачи участнику долевого строительства Объекта долевого строительства уже застройщик попадает на штрафные санкции.

Кроме того, застройщик вправе заключать с долевым участником договор долевого строительства и принимать деньги только после того, как оформит в собственность или аренду земельный участок и получит разрешение на строительство дома ${ }^{12}$. Поэтому нарушение застройщиком требований Ф3 о долевом строительстве, предъявляемых к проектной декларации, дает право участнику долевого строительства обратиться в суд с иском о признании договора недействительным, поскольку участник мог быть введен в заблуждение. В данном случае застройщик должен будет вернуть полученные в рамках договора денежные средства и уплатить на них проценты.

Немаловажными являются статьи договора, посвященные вопросам гарантии качества объекта долевого строительства, который должен соответствовать требованиям технических регламентов, проектной документации и градостроительных ре-

\footnotetext{
12 См.: Правовое регулирование инвестиций в жилищном строительстве. Долевое участие граждан в инвестировании строительства жилья./http://portal-law.ru/articles/strinv.
} 


\section{Политика и общество 2 (98) • 2013}

гламентов, а также иным обязательным требованиям, установленным действующим законодательством. Причем если требования к качеству объекта не соблюдены, участник долевого строительства в одностороннем порядке вправе отказаться от исполнения договора и потребовать от застройщика возврата денежных средств и уплаты процентов за пользование указанными денежными средствами.

Что касается процесса передачи объекта долевого строительства, то последний осуществляется путем подписания передаточного акта в течение двух месяцев с момента получения разрешения на ввод в эксплуатацию многоквартирного дома. В передаточном акте указаны подробные характеристики объекта долевого строительства или его части: местонахождение, общая и жилая площадь, исполнение обязательств по договору, отсутствие взаимных претензий. После завершения строительства инвестор получает право оформить построенный объект в собственность.

В свою очередь, в целях обеспечения исполнения обязательств застройщика с момента государственной регистрации договора у участников долевого строительства находятся в залоге следующие объекты: объект долевого строительства, жилые и нежилые помещения в многоквартирном доме; объект незавершенного строительства; земельный участок, принадлежащий застройщику на праве собственности, или право аренды на указанный земельный участок; объекты незавершенного строительства, строящийся (создаваемый) на этом земельном участке многоквартирный дом. Право залога не распространяется на объект долевого строительства с момента подписания сторонами передаточного акта.

Следует заметить, что потребитель (а в данном случае потребителем является участник долевого строительства - соинвестор) по определению является самым уязвимом звеном в гражданско-правовом обороте. Поэтому очень важно, чтобы при инвестиционной деятельности граждан соблюдались простота, доступность, и были в достаточной степени защищены их права как инвесторов. Поэтому правовое сопровождение инвестиций граждан должно основываться на простых и в достаточной мере защищенных легальных, типовых моделях потребительских инвестиций ${ }^{13}$.

\footnotetext{
${ }^{13}$ См.: Литягин Н.Н. Частноправовое и публично-правовое регулирование инвестиций в Российской Федерации: гражданско-правовой и финансово-правовой аспекты/Н.Н. Литягин: Монография - М.: Изд-во РГТЭУ. 2011. С. 100.
}

Полагаем, что договор долевого участия как раз и выполняет такую функцию - дает возможность гражданам вступать в инвестиционные отношения на вполне прозрачных условиях.

В самом ФЗ о долевом строительстве закреплено три положения, способствующие защите интересов, это: запрет на проведение работы, рекламы и продажу до момента появления полного пакета разрешений на строительство; предусмотрено наказание за просрочку ввода дома в эксплуатацию; обязательна государственная регистрация. Более того, если договор заключается гражданином, который приобретает право исключительно для личных, семейных, домашних и иных нужд, не связанных с осуществлением предпринимательской деятельности, помимо гарантий, предусмотренных сами Ф3 о долевом участии, применяется законодательство РФ о защите прав потребителей в части, не урегулированной настоящим федеральным законом.

В целях системного контроля в сфере инвестирования в жилье в системе исполнительной власти должен быть определен федеральный орган, уполномоченный осуществлять государственное регулирование, контроль и надзор в области долевого строительства многоквартирных домов и иных объектов недвижимости. Этот орган должен быть наделен широкими полномочиями в отношении застройщиков.

Таким образом, можно смело сказать, что ФЗ о долевом строительстве, который наконец-то снял значительную часть вопросов, связанных с правовым регулированием инвестиционной деятельности в жилищном строительстве, способствует установлению стабильности в отношениях, складывающихся между застройщиками и долевыми участниками. Крайне важно, что сам Ф3 о долевом участии указывает на то, что частные инвесторы - граждане, вступающие в отношения, не связанные с извлечением прибыли, находятся под защитой не только настоящего закона, но и в целом на эти отношения распространяется законодательство о защите прав потребителей.

Предусмотренная указанным федеральным законом гражданско-правовая конструкция договора участия в долевом строительстве должна способствовать развитию инвестиционных отношений, комплекс которых в России на сегодняшний день в полной мере сформирован. Тем не менее, как справедливо отмечается некоторыми авторами, состояние законодательного регулирования этих отношений «не позволяет создать достаточно эффективную инвестиционную 
сферу, что негативно сказывается на перспективах развития отечественной экономики» ${ }^{14}$. Это означает, что законодателю, да и всему обществу в целом все еще есть к чему стремиться.

\section{Библиография:}

1. Власова А.Ю. Категория «инвестиции» в российском законодательстве./Внешнеторговое право. 2007. № 1. С. 34 .

2. Илюшина М.Н. Правовой режим сделок в коммерческих отношениях: вопросы становления в доктрине, законодательстве и правоприменительной практике: монография. М.: РПА Минюста России, 2011. С. 159.

3. Инвестиционная активность населения на рынке жилищного строительства: Моногр./И.Ф. Кульков А.А., Рожков В.Л., Харисова Р.Р., Казанский гос. арх.-строит. ун-т, Объед. молод. строительства РТ. - Казань, РЦМИПП, 2011. С. 47.

4. Козлова Е.Б. Инвестиционный договор: понятие и место в системе гражданско-правовых договоров по дихотомическому принципу: монография / Е.Б. Козлова; РПА Минюста России. - М., 2011. С. 69.

5. Литягин Н.Н. Частноправовое и публично-правовое регулирование инвестиций в Российской Федерации: гражданско-правовой и финансово-правовой аспекты/Н.Н. Литягин: Монография - М.: Изд-во РГТЭУ. 2011. С. 100.

6. Правовое регулирование инвестиций в жилищном строительстве. Долевое участие граждан в инвестировании строительства жилья. / http://portal-law.ru/articles/strinv.
7. Сокол П.В. Инвестиции в жилищное строительство: понятие и правовые формы.// Законы России: опыт, анализ, практика. 2011. № 1. C. $23-29$.

\section{References (transliteration):}

1. Vlasova A.Yu. Kategoriya «investitsii» v rossiyskom zakonodatel'stve.//Vneshnetorgovoe pravo. 2007. № 1. S. 34.

2. Ilyushina M.N. Pravovoy rezhim sdelok v kommercheskikh otnosheniyakh: voprosy stanovleniya v doktrine, zakonodatel'stve i pravoprimenitel'noy praktike: monografiya. M.: RPA Minyusta Rossii, 2011. S. 159.

3. Investitsionnaya aktivnost' naseleniya na rynke zhilishchnogo stroitel'stva: Monogr./I.F. Kul'kov A.A., Rozhkov V.L., Kharisova R.R., Kazanskiy gos. arkh.stroit. un-t, Ob'ed. molod. stroitel'stva RT. - Kazan', RTsMIPP, 2011. S. 47.

4. Kozlova E.B. Investitsionnyy dogovor: ponyatie $i$ mesto v sisteme grazhdansko-pravovykh dogovorov po dikhotomicheskomu printsipu: monografiya / E.B. Kozlova; RPA Minyusta Rossii. - M., 2011. S. 69.

5. Lityagin N.N. Chastnopravovoe i publichno-pravovoe regulirovanie investitsiy $\mathrm{v}$ Rossiyskoy Federatsii: grazhdansko-pravovoy i finansovo-pravovoy aspekty/N.N. Lityagin: Monografiya - M.: Izd-vo RGTEU. 2011. S. 100

6. Sokol P.V. Investitsii v zhilishchnoe stroitel'stvo: ponyatie i pravovye formy.// Zakony Rossii: opyt, analiz, praktika. 2011. № 1. S. $23-29$.

${ }^{14}$ См.: Власова А.Ю. Категория «инвестиции» в российском законодательстве.//Внешнеторговое право. 2007. № 1. С. 34. 